\title{
ASSESSING EMPLOYER SATISFACTION: AN ATTEMPT TO ENHANCE GRADUATE EMPLOYABILITY AT AN INSTITUTION OF HIGHER LEARNING
}

\author{
H. J. Brits \\ Quality Promotion Unit \\ Vaal University of Technology \\ Vanderbijlpark, South Africa \\ e-mail: hansb@vut.ac.za
}

\section{ABSTRACT}

This article discusses the concept employability or graduateness within the context of the South African higher education environment. It reflects on a satisfaction survey that was conducted at a university of technology in order to evaluate the perspective and satisfaction of the graduates' employers. This aligns with the institution's quality management philosophy that is underpinned by the notion of customer satisfaction. The survey measured the employers' satisfaction as well as their perspectives on the importance of attributes that are required from graduates in the workplace. The article argues that institutions should develop strategies to embed key skills in the curricula and recommends continuous reviews to evaluate the successful implementation of these strategies to enhance employability.

Keywords: employability satisfaction surveys, skills attributes, quality assurance

\section{INTRODUCTION}

Institutions of higher learning find themselves under enormous strain to produce graduates (Bridgstock 2009) that are employable and to address employer dissatisfaction vis-á-vis graduates' attributes (Shah and Nair 2011). "The growing emphasis on graduate attributes in higher education has several sources" (Hager and Holland 2006, 3), of which one is the demands from employers for graduates to hold generic attributes and secondly, the purpose of higher education institutions as establishments that develop employable graduates. Institutions of higher learning are characterised by two forms of instrumental learning, "on the one hand is the instrumentalism of the discipline apprenticeship ... (and) on the other hand is the instrumentalism associated with employability" (Harvey 2000, 9). Institutions should, therefore, according to Harvey $(2000,9)$, "attempt to predict and plan for skills gaps".

The higher education sector is a key role player not only in enhancing employability but also to impact on national economic growth. According to Statistics South Africa (2017), the country's unemployment rate stands at an alarming 26.5 per cent of the total working-age 
population (see Table 1). The unemployment rate in South Africa averaged 25.37 per cent from 2000 until 2016; it reached an all-time high of 31.20 per cent in the first quarter of 2003 and a record low of 21.50 per cent in the fourth quarter of 2008. It is evident that the South African economy is not performing well in terms of employment growth and job creation (Moleke 2010). Like many governments abroad, the South African government intensified the pressure on the higher education sector to play its role in enhancing economic stimulation and growth and to ensure that the national workforce is highly skilled and globally competitive. According to Chetty $(2012,19)$, "it has been widely acknowledged that higher education plays a significant role in human capital development and economic growth".

According to Statistics South Africa (2017), employed persons with a higher education qualification was highest among white and Indian population groups. A total of 47.3 per cent of employed white population and 29.7 per cent of employed Indian population had a tertiary qualification. The share of employed with tertiary qualification among the black and coloured population was only 16.2 per cent and 13.3 per cent respectively. Statistics for 2015 and 2016 show that more than 50 per cent of the employed black and coloured population had education levels of less than matric.

Higher education is responsible to prepare students as skilled employees for future employment that can compete within a shrinking global workforce (Griesel and Parker 2009). The higher education sector in South Africa "is becoming increasingly aware of the need for a more seamless interface between higher education and the workplace" (Chetty 2012, 8). In order to enhance employability of graduates, institutions of higher learning should evaluate the views and expectations of employers on a continuous basis. The information gathered from these evaluations can assist curriculum developers to align curricula with key skills needed for the workplace or to initiate remedial plans that will enhance graduateness. Harvey $(2000,3)$ warns that when dealing with the relationship between the academy and employment, it should not be seen as an "apologist for anti-intellectualism, for the erosion of academic freedom and as proposing that higher education should be about training graduates for jobs rather than improving their minds". According to Harvey (2000), the new reality for higher education in a rapidly changing world is responsiveness and should not be the downgrading of higher education training.

Notwithstanding the research conducted by inter alia Griesel and Parker (2009), there is a dearth of research within the South African context on graduate attributes from the perspective of employers. A satisfaction survey was conducted in 2016 with employers of graduates that completed their studies at the Vaal University of Technology (VUT) during 2010-2015. This article reflects on a customer satisfaction survey, which forms part of a quality assurance 
initiative of VUT to determine employer satisfaction, which underpins the philosophy of total quality management (TQM). This article will discuss the current discourse on graduateness, employability and the notion of customer satisfaction, which underlie the institution's quality management philosophy. It reflects on the methodology followed during the satisfaction survey, including the results of the survey, culminating in conclusive remarks and recommendations that might have relevancy for related studies in the sector.

\section{GRADUATENESS AND EMPLOYABILITY}

Institutions of higher learning are responsible to produce, among other things, graduates who have the attributes required for the workplace. According to Griesel and Parker $(2009,4)$, there needs to be a move away from grooming graduates for the workplace towards the notion of employability and to re-frame what it means to be "a graduate" or "graduateness". The concept graduateness is defined by Grant $(2010,7)$ as "a job-literate, technically numerate, professionally skilled, communicatively competent and ethically sound graduate ready for the world of work". Graduateness, therefore, is employability (Eccles 2012, 107). The current emphasis on graduateness can be viewed as an assumption that the future of the workplace is "collective rather than isolated" (Winch 2006, 75). There is a gradual change in the meaning of the concept "graduateness" towards a concept that involves the achievement of an escalating knowledge-driven world (Griesel and Parker 2009). Winch $(2006,69)$ views graduateness of higher education qualifications as attributes that were developed to include knowledge, skills and attitudes, which the modern workplace requires. Within the context of higher learning, the concept graduate attributes refer to "a very diverse range of supposed 'things' - skill components, attitudes, values and dispositions" (Hager and Holland 2006, 3). Hager and Holland $(2006,3)$ prefer to use the concept attributes as it is a more neutral term to refer to a collection of diverse qualities that together constitute the concept generic skills. Skills that are expected of graduates are numerous; the skills associated with subject-specific knowledge usually are described as hard skills. The skills that refer to the ability to do something "based more on attitude and behaviour" are referred to as soft skills (Chetty 2012, 10). This study focuses on soft skills that are described in literature as generic-, transferable-, core- or key skills. Employees require, within knowledge-based economies, a wide range of generic attributes such as the ability to work flexibly as members of a team, to work autonomously, the capacity to adapt to change, the ability to work creatively and so forth (Hager and Holland 2006, 4).

Winch $(2006,69)$ emphasises that not all attributes are transferable, for example "an ability that is specific to a particular subject" is not transferable, while an item that is learned and that can be transferred outside the specific subject matter may be regarded as generic. This 
is also the opinion of Laybourn, Falchikov, Goldfinch and Westwood $(2000,48)$ and they opine that all generic skills are not transferable, "there appears to be very little empirical evidence concerning the transferability of generic skills". This article will use the concept graduate attributes when referring to generic skills or generic attributes within the context of the higher education sector.

Governments are strengthening the role of tertiary institutions in many countries since they are viewed as instrumental in enhancing national economy. In order to counteract on the unemployment pandemic in South Africa, the government initiated plans on a national level such as the New Growth Path (NGP) with the aim to improve job creation. There is a clear relationship between graduateness and employability (Chetty 2012, 8). In this article, the concept graduateness concurs with the position of Glover, Law and Youngman (2002), namely graduateness are the skills, knowledge and understanding that graduates possess, while employability is considered as the capacity or ability of graduates to enter the workplace. Globally, employers express their concern pertaining to graduates that fail to compete on a global level as a result of their lack of essential skills (Jackson 2009). According to Jackson (2009), the global economic crisis serves to highlight the proliferation of employers' requirements for new graduates.

New graduates, as employees, are expected to add immediate value to businesses. According to Moleke (2010), in the higher education sector there is a misalliance between graduate output and the needs and expectations of the labour market, especially with regard to the types of qualifications and skills required. Institutions of higher learning can rectify this mismatch because it is their moral purpose to address the changing needs and expectations of employers (Shah and Nair 2011). According to Harvey (2000, 3-4), the higher education sector has a transformational role to play in empowering its learners to become transformative agents in society. This requires a relationship between employers and higher education, which should not be perceived as a nexus in isolation, or an "add-on" to academic study. Harvey $(2000,4)$ states that employability of graduates should not be the main focus, but rather a "subset of, and fundamentally contingent on, transformative lifelong learning".

However, regarding the above-mentioned pressure on tertiary institutions to produce graduates that are employable (Bridgstock 2009), controversy prevails concerning what constitutes employability as well as the attributes required by employers that will result in the promotion of graduate employability. A concern on a global level is that the existing undergraduate programmes are not producing graduates with the types of skills needed that will also ensure lifelong learning and a successful professional career.

As already mentioned, employers have expressed their concern about graduates' poor 
skills, which are essential for competing on a global level (Jackson 2009). The global level is characterised with a volatile economy and a rising unemployment environment. Against this background, South Africa, like many other countries, should produce graduates who can compete within a dwindling global workforce (Griesel and Parker 2009). The unemployment rate in South Africa is alarmingly high. It averaged 25.37 per cent from 2000 until 2016, reaching an unsurpassed high of 31.20 per cent in the first quarter of 2003 and a record low of 21.50 per cent in the fourth quarter of 2008 (Statistics South Africa 2017).

Table 1: South Africa unemployment rate updated March 2017

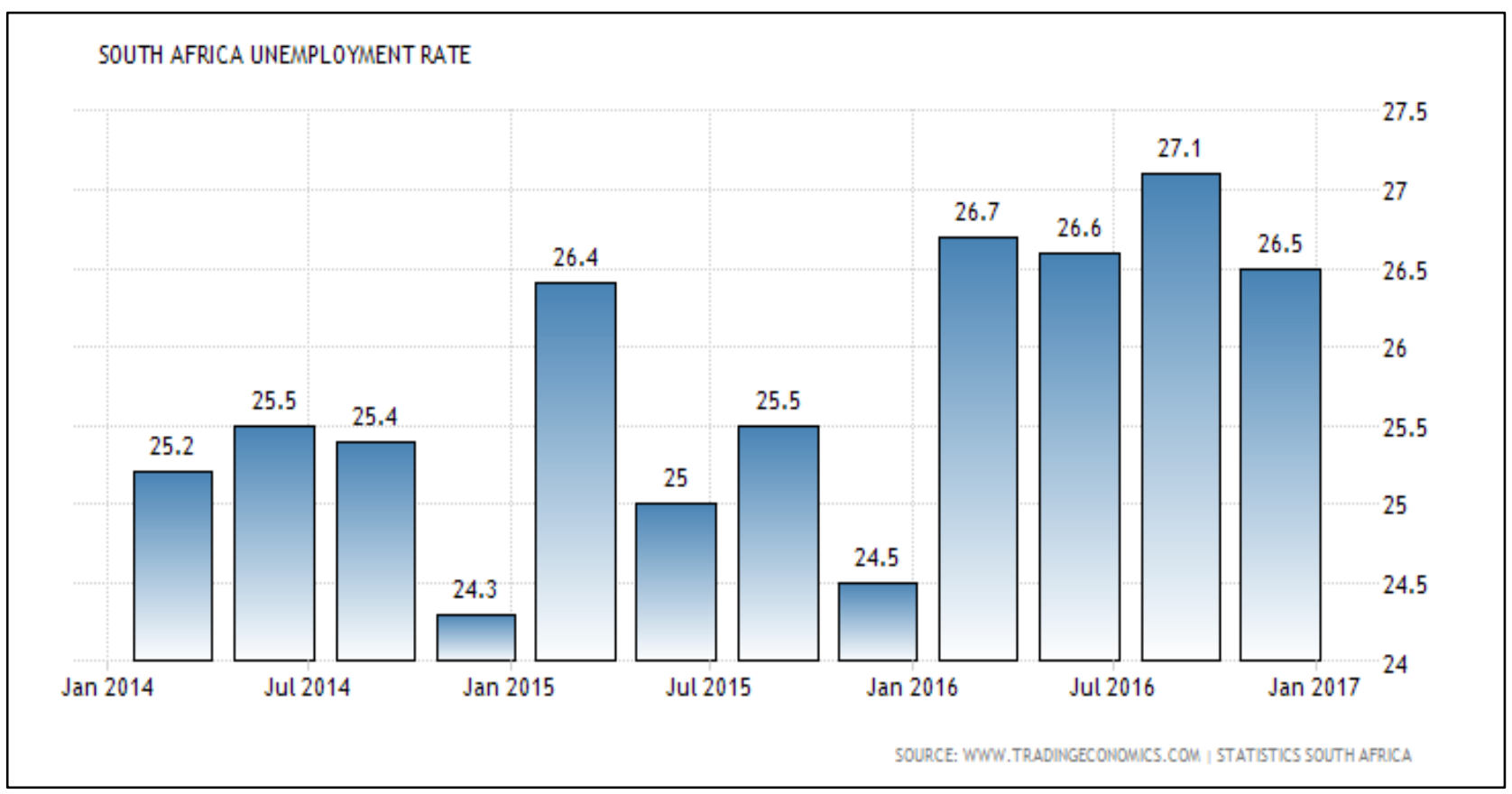

As already mentioned, in many developing countries, including South Africa, the focus is on higher education institutions to contribute to the national economy. South Africa's National Development Plan (2011) states that institutions of higher learning in South Africa play three main roles in society, namely to educate and train people with high-level skills for the employment needs of the public and private sectors and to equip people with new knowledge for a changing society and economy. The moral purpose of institutions of higher learning is to meet the changing needs of employers and industry (Shah and Nair 2011) and produce graduates that are more employable (Bridgstock 2009).

According to the White Paper on Education (RSA 1997) the purpose of higher education is to cater to individuals' learning needs and aspirations by means of developing their intellectual abilities throughout their lives. This concurs with Harvey's $(2000,5)$ emphasis on 
transformative lifelong learning as the primary focus of higher education. The White Paper on Education (RSA 1997) emphasises the fact that the higher education sector is responsible to address the development needs of society and provide a knowledge-driven and knowledgedependent society.

While universities are placed under increasing pressure to produce graduates that are employable (Bridgstock 2009), controversy exists regarding what constitutes employability and what attributes warrant employability. In South Africa, universities of technology have focused for many years on vocationally-orientated programmes with a strong emphasis on workintegrated learning. A closer link between universities and external stakeholders with the aim to enhance employability may develop a concern amongst members of the higher education sector that it might impact on academic freedom.

Universities differ about what they regard as graduate attributes. There is also a difference in the nature and level of attainment of attributes. This can vary from simple technical skills to more complex intellectual competencies and ethical values (Barrie 2006). The South African Qualifications Authority (SAQA), in collaboration with Higher Education South Africa (HESA), conducted on national level a study on graduates in South Africa from an employer perspective (Griesel and Parker 2009). This study mentioned that employability is:

“... influenced, in the main by four broad and inter-related components: skilful practices (communication, management of time, self and resources, problem-solving and lifelong learning); deep understandings grounded in a disciplinary base (specialised expertise in a field of knowledge); efficacious beliefs about personal identity and self-worth; and metacognition (selfawareness and the capability to reflect on, in and for action)" (Griesel and Parker 2009, 5).

These components are regarded by Griesel and Parker $(2009,5)$ as the deep notion of employability. According to Harvey (2000, 8), employers require employees with communication, teamwork and interpersonal skills as their personal attributes. Employers with interactive attributes can communicate effectively (formally and informally), they feel comfortable to work with people at all levels of an organisation, they work effectively in teams and they are flexible to re-adjust their roles from one project situation to another. Personal attributes and abilities include, amongst others in Harvey's (2000) study intellect, knowledge, willingness and ability to learn, continuous learning, willingness to take risks and to show initiative, self-motivation, self-confidence and self-management.

Employers want graduates with different kinds of experience (Harvey 2000, 7), which includes working experience. Institutions' cooperative education programmes offer students work-integrated learning initiatives. These programmes are narrowing the gap between theory and practice. Rainsbury, Hodges, Burchell and Lay (2002), state that cooperative education 
programmes are preparing students for the workplace by developing useful generic and specific skills. It makes "a distinctive contribution to the student's knowledge base and to his or her socialization into the occupation" (Eraut 2002, 6).

\section{EMPLOYER SATISFACTION}

The principles of the quality management system of the Vaal University of Technology (VUT) are underpinned by the philosophy of TQM. From a TQM point of view, it is imperative that customers' needs are recognised and discovered, that standards are set that are consistent with customer requirements (Oakland 1998, 27). Central to this approach is stakeholder or customer satisfaction. VUT regards its students and staff members as internal stakeholders and government, industry and all other role players as external stakeholders.

According to the study of Shah and Nair (2011), the higher education sector, to a large extent, is responsible for graduates' attributes not being to the satisfaction of employers. The notion of continuous improvement (Oakland 1998, 124), which refers to the "efforts of universities to continually improve their quality" (Manatos, Sarrico and Rosa 2016, 145) and customer satisfaction (Oakland 1998, 124) is central to the philosophy of TQM. The TQM approach, therefore, can be regarded as a customer-centred approach. VUT should determine the needs and expectations of its employers as external stakeholders and the satisfaction of employers with the graduates of VUT that they employed. Satisfaction surveys can be used as a quality management mechanism to generate data and information as a "factual approach to decision-making" (Manatos et al. 2016, 145). The results of the study should inform the development and alignment of academic programmes as an attempt to enhance graduate employability and counteract employer dissatisfaction.

\section{METHODOLOGY}

To determine the satisfaction of VUTs employers with the skills and attributes of its graduates that entered the labour market in the past five years, an employer satisfaction survey was conducted in 2016. As already mentioned, the purpose of the survey was not only to determine the satisfaction of employers with the graduates but as a quality assurance mechanism to collect information that will feed into remedial action initiatives as an attempt to enhance VUT graduates' employability and to counteract employer dissatisfaction.

Graduates concerned received their training from four faculties namely, Applied and Computer Sciences, Engineering and Technology, Human Sciences and Management Sciences. A questionnaire was developed in collaboration with Quantemna, an external research company. The questions were informed by a literature study that was conducted. In order to 
address the objectives of the study, the following sections were included in the questionnaire:

- Organisational information

- Graduate attributes in the workplace

- $\quad$ Knowledge and skills

- $\quad$ Changing workplace practices

- Building social cohesion

The above-mentioned external research company administered the survey. The Director Quality Promotion of VUT acted as the study leader of the project. The Google Forms online survey platform was used to upload the questionnaire, after which it was tested for accuracy. The sample consists of employers of VUT graduates from companies where graduates mostly were employed per an alumni database. In general, employers received emails that advertised the survey via the respective companies' human resource departments. The questionnaire was active for completion online from 1 September 2016 to 31 October 2016.

Data were downloaded for the Google Forms online survey platform into the Microsoft Excel software programme. Quantitative data were checked and cleaned and thereafter uploaded into the Statistical Package for Social Sciences (SPSS) software programme for statistical analysis. Descriptive statistics were run in SPSS for all quantitative questions and graphs and infographics were created to represent the data from the frequency tables produced visually. The total sample for the study comprised of 119 employers from various organisations within South Africa $(\mathrm{N}=119)$.

The participants were requested to rate their perceived satisfaction with the performance of VUT graduates that they employed by means of a questionnaire. The questionnaire makes provision for respondents to indicate the importance of and their satisfaction with the various graduate attributes that are phrased as questions. The questionnaire measures the satisfaction or dissatisfaction of the respondents (employers) with the VUT graduates' attributes in the workplace. A question with a high response value for importance but a low satisfaction value is an indication that the respective attribute is highly required by the employer but that the employer (respondent) is not satisfied with the graduates' performance in relation to the specific attribute. The questionnaire assists VUT to identify those attributes that are regarded by the employers (respondents) as not that important (questions with low response values for importance). The information gathered from the survey will help VUT to identify the most important attributes that are required from its employers. 


\section{RESULTS}

The data gathered from the survey were clustered under the following categories:

- Employment sector (Construction, gas, education, electricity, accommodation and food service activities, steam and air-conditioning supply, waste management, mining and quarrying, professional, manufacturing, retail, remediation, scientific and technical activities, sports management, tourism, sewerage, transportation and water supply).

- General skills (English proficiency, verbal and written communication skills, listening skills, organising information for presentations, critical thinking skills, computer literacy, reading, use of equipment for technology specific to the work environment, leadership, teamwork and customer service).

- Work-related knowledge and understanding (Employee's knowledge in of his/her field of study, grasp of work related information, specific technical knowledge and relevant computer applications required for the job, understanding of organisational context and prior exposure to the work environment).

- Workplace skills and applied knowledge (Capability to relate knowledge to new situations and connect specific issues to wider organisational context, ability to identify problematic situations and choose appropriate information to address problems, suitable problem solving methodologies, skills to plan and execute tasks independently and monitor and evaluate own activities, ability to develop ways to enhance own actions, skills to deal with diverse cultural traditions and understanding workplace customs).

- $\quad$ Other (The questionnaire requested the respondents to mention other qualities that are generally expected of employees).

\section{Overview of employment sector}

Participants were asked to classify the organisation that they work for in terms of major industry or employment sector. The majority of participants (32.8\%) indicated that they work in the manufacturing industry. 11.8 per cent of the participants work for the mining and quarrying organisations, a further 10.1 per cent indicated that they are involved in professional, scientific and technical activities. The rest include agriculture, applied biotechnology, arts, local government, medical technology, retail and clothing, sports management and tourism, amongst others. 


\section{General skills}

Participants rated their satisfaction with how well trained the employee was in each of the general skills. The concept general skill in this study refers to typical skills expected of most employees with a higher education qualification. The skill of critical thinking was rated as the most important with 98 per cent of participants indicating that this skill is very important for the successful performance of the job.

Listening skills and teamwork also received high ratings of 97 per cent and 96 per cent. 43 per cent of the participants specified that they were to a lesser degree satisfied with the graduates' demonstration of leadership, while 7 per cent were dissatisfied. Although the satisfaction value for leadership was in general low (50\%), it was the attribute with the lowest value of importance. Two attributes, namely ability to organise information for presentations and critical thinking have a significantly high "gap" of 30 per cent + each (low satisfaction value with a high importance value).

A final question on general skills measured the participants' overall satisfaction with the general skills demonstrated by the VUT graduates that they employed. 52.9 per cent were very satisfied, and 8.4 per cent were extremely satisfied. 26.9 per cent where somewhat satisfied and 5.9 per cent were dissatisfied with the generic skills of VUT graduates.

\section{Work-related knowledge and understanding}

The work-related items received a high importance rating. The only exception was for the aspect of having "prior exposure to the working environment"; what is interesting is that only 52 per cent of the participants rated this aspect as important. Aspects such as "understanding work related information" (97\%), "knowledge in the employee's" (94\%) and "specific technical knowledge that is required for the job" (92\%) were rated as very important. Significant gaps $(30 \%+)$ between satisfaction and importance values were "understanding" of job-related information (97\% importance and 67\% satisfaction) and "specific technical knowledge required for the job" (92\% importance and 59\% satisfaction). The response of the participants on the overall satisfaction with VUT employees with regard to "work-related knowledge and understanding demonstrated" were 45 per cent of the participants satisfied, 32 per cent somewhat satisfied, 12.6 per cent not very satisfied and 4.2 per cent not satisfied.

\section{Workplace skills and applied knowledge}

The participants rated, in general, relatively high values for the importance of the aspects "workplace skills and applied knowledge" (between 94\% and 80\%). Aspects with significantly high importance values were "ability to apply knowledge to new situations", "ability to 
recognise a problem situation", ability to choose appropriate information to address problems", "appropriate approach to problem solving" and "ability to devise ways to improve on own actions". VUT should take cognisance of the significantly high $(30 \%+)$ gap between the satisfaction value and importance value of the following aspects related to workplace skills and applied knowledge, "ability to recognise a problem situation", "appropriate approach to problem solving", "ability to relate specific issues to wider organisational context" and "ability to monitor and evaluate own work-related actions".

\section{Other qualities expected of employees}

The participants were presented with the following 10 employee qualities that were not listed under the above-mentioned categories: flexibility, creativity, empathy, reliability, integrity, self-discipline, positive attitude towards work, willingness to learn, understand and takes directions for work assignments and accepts responsibility for consequences of actions. Qualities that received significantly high importance values $(90 \%+)$ were flexibility, reliability, integrity, self-discipline, positive attitude towards work, willingness to learn, understand and takes directions for work assignments and accepts responsibility for consequences of actions. The satisfaction rate for flexibility was also significantly high $(93 \%)$.

\section{Building social cohesion}

Social diversity of cultural and religious practices, identities and languages are characteristic of the South African context. Participants were asked to indicate the extent to which they agree or disagree that VUT has equipped graduates to contribute towards the building of social cohesion. 73 per cent of the participants agree that the institution equipped graduates to contribute towards the building of social cohesion within the workplace. Only 1.6 per cent of the participants disagree with this statement.

\section{RECOMMENDATIONS}

The study shows that all dimensions of general skills that were measured were rated as important (more than $70 \%$ importance). Reading abilities was a skill that received a significantly high satisfaction rating (76\%). Regarding job-related knowledge and understanding, there was a significant discrepancy between what employers perceived as important in comparison to their satisfaction rating. Discrepancies also were found in workplace skills and applied knowledge. The satisfaction rate for this category was significantly lower than the importance rates. The majority of respondents $(50.4 \%)$ were very satisfied with the graduates' demonstration that they mastered these skills. As high as 93 per cent of the 
respondents were satisfied with the graduates' ability to prove that they are flexible in the workplace. The respondents, in general, were satisfied with the way in which VUT succeeded to prepare graduates with knowledge and skills that will help them to adapt to a constantly changing workplace and their ability to build a social cohesion within the workplace.

From a teaching and learning point of view, the identification of generic attributes are, according to Hager and Holland (2006, 7), "significant components of initiatives to improve teaching and learning". The satisfaction and importance rates per question offer the institution an opportunity to determine the gap between importance and satisfaction rate. This helps the institution to eliminate the aspects that have a significantly high importance value but a low satisfaction level. According to Winch $(2006,82)$, institutions should investigate if generic attributes exist by means of curricula reviews. These reviews can be conducted as part of an institution's quality assurance initiatives of cyclical programme reviews. Castley and Stowel $(1998,27)$ state that staff are expected to ensure that courses develop and assess a range of key skills and that students should have an opportunity to review their personal and academic development with reference to such skills.

From a quality assurance point of view, all aspects with a significantly high importance but a low satisfaction rate, as well as the results of curricula reviews, should be translated into remedial action initiatives and curriculum development interventions. Aspects with a high satisfaction but low importance rate can be eliminated and be viewed as not important at all. This information can help to develop and to refine an institutional list of existing graduate attributes and can identify the aspects that are regarded as of high value to the employer.

VUT should consider strategies to embed key skills in the curricula. The study of Chapple and Tolley $(2000,76)$ shows that the embedding of skills "within the curriculum of a large and complex higher education institution is a far from easy process". Academic departments ought to select the skills that should be embedded within the curriculum while the university implements strategies to develop teaching innovations from within. The embedding of skills in the university will enhance not only the learning experience of students but also employer satisfaction. VUT can consider using departmental level key stakeholders that can act as change agents similar to the practice of the University of Nottingham (Chapple and Tolley 2000, 70). At the University of Nottingham, departmental leaders were appointed to monitor and coordinate key skills development within their individual departments. Staff capacity building exercises are imperative, institutional staff development programmes should focus on different approaches to develop students' key skills. These exercises will stimulate an institutional discourse on skills development and assessment and how it can be embedded within the curricula. The study of Fallows and Steven (2000) at the University of Luton, was conducted 
to embed a range of core skills within the university's undergraduate programmes. They use a detailed skills template that "describes skills development expectations at each level of undergraduate study" (Fallows and Steven 2000). All students leave the University of Luton with a transcript that recognises the graduates' skills experience alongside with their academic records.

\section{CONCLUSION}

This article focuses on an employer satisfaction survey that was conducted at VUT by using satisfaction survey questionnaires, which offer the respondents an opportunity to rate their satisfaction level with VUT graduates' attributes as well as the importance of a respective attribute. This instrument assists the institution in identifying the key attributes and skills that VUTs employers require and helps the institution to eliminate the attributes and skills that are not high in demand. The article reflects on areas of satisfaction and dissatisfaction with VUT graduates' skills and attributes and discusses the key skills and attributes needed in early career graduates to meet the changing industry trends in various professions. It concludes with recommendations on strategies that should be in place to identify student attributes that are required from employers and the importance of regular curricular reviews to assess the existence of key attributes.

These activities may stimulate discourse at institutional level on student attributes and skills and, based on studies conducted at several universities abroad, the development and implementation of strategies to embed key skills in the curricula. Harvey $(2000,11)$ emphasised that "embedded approaches to skill acquisition give employability skills the same status as knowledge and oblige all lecturers to address them". Continuous processes of employer and student satisfaction reviews (e.g. satisfaction surveys and student class feedback) should be conducted as part of an institution's quality assurance mechanisms to monitor the successful implementation of curricula (with embedded key skills) and to ensure an employer and student voice in the enhancement of the learning experience and employer satisfaction.

Hinchliffe $(2006,91)$ asks a valid question: Can we really expect from young people in their early twenties to acquire all skills and attributes, which will take an average intelligent person many years to develop? Are the expectations for new graduates realistic? In other words, is there a need for a degree of realism to these expectations? These questions require further research in the quest to develop student graduateness and employability.

\section{REFERENCES}

Barrie, S. 2006. Understanding what we mean by the generic attributes of graduates. Higher Education 
51(2): 215-241.

Bridgstock, R. 2009. The graduate attributes we've overlooked: Enhancing graduate employability through career management skills. Higher Education Research and Development 28(1): 31-44.

Castley, A. and M. Stowell. 1998. Embedding capability in the curriculum: Case study from the BA and BSc combined honours course at Nene University College Northampton. In Capability and quality in higher education, ed. J. Stephenson and M. Yorke. London: Kogan.

Chapple, M. and H. Tolley. 2000. Embedding key skills in a traditional university. In Integrating key skills in higher education, ed. S. Fallows and C. Steven. London: Kogan.

Chetty, Y. 2012. Graduateness and employability within the higher education environment: A focused review of the literature. In Developing student graduateness and employability: Issues, provocations, theory and practical guidelines, ed. M. Coetzee, J. Botha, J. Eccles and N. Nienaber. Randburg: Knowres.

Eccles, N. 2012. The subversion of graduateness by an obsession with employability? In Developing student graduateness and employability: Issues, provocations, theory and practical guidelines, ed. M. Coetzee, J. Botha, J. Eccles and N. Nienaber. Randburg: Knowres.

Eraut, M. 2002. Developing professional knowledge and competence. London: Routledge Falmer.

Fallows, S. and C. Steven. 2000. Building employability skills into higher education: A university wide initiative. In Education and Training 42(22): 75-83, ed. C. Sarrico, P. Texeira, A. Magalhaes, A. Veiga, M. Rosa and T. Carvalho.

Glover, D., S. Law and A. Youngman. 2002. Graduateness and employability: Student perceptions of the personal outcomes of university education. Research in Post-Compulsory Education 7(3): 329-306.

Grant, T. 2010. From the classroom to the boardroom - higher education strategies for enhancing professional communication practice and graduateness for a global workplace. In Enquiry, autonomy and graduateness: Achieving an outstanding student learning experience, ed. C. Corker. Sheffield: CPLA Conference, 15-17 June.

Griesel, H. and B. Parker. 2009. Graduate attributes: A baseline study on South African graduates from the perspective of employers. HESA and SAQA. www.saqa.org.za/docs/genpubs/2009/graduate_ attributes.pdf (Accessed 10 February 2017).

Hager, P. and S. Holland. 2006. Introduction. In Graduate attributes, learning and employability, ed. P. Hager and S. Holland, 1-15. Dordrecht: Springer.

Harvey, L. 2000. New realities: The relationship between higher education and employment. Tertiary Education and Management. https://qualityresearchinternational.com/essecttools/relatedpubs/ New\%20.Realities.pdf (Accessed 11 March 2017).

Hinchliffe, G. 2006. Graduate employability and lifelong learning: A need for realism? In Graduate attributes, learning and employability, ed. P. Hager and S. Holland, 91-104. Dordrecht: Springer.

Jackson, D. 2009. An international profile of industry-relevant competencies and skill gaps in modern graduates. International Journal of Management Education 8(3): 29-58.

Laybourn, P., N. Falchikov, J. Goldfinch and J. Westwood. 2000. Evolution of skills development initiatives. In Integrating key skills in higher education: Employability, transferable skills and learning for life, ed. S. Fallows and C. Steven. Kogan Page: London.

Manatos, M. J., C. S. Sarrico and M. J. Rosa. 2016. The integration of quality management in universities. In Global challenges, national initiatives, and institutional responses: The transformation of Higher Education. Higher Education Research in the $21^{\text {st }}$ century, ed. C. Sarrico, P. Texerira, A. Magalhaes, A. Veiga, M. J. Rosa and T. Carvalho. Rotterdam: Sense.

Moleke, P. 2010. The graduate labour market. In Student retentions and graduate destination: Higher education and labour market access and success, ed. M. Letseka, M. Cosser, M. Breier and M. Visser, 87-96. Cape Town: HSRC Press.

Oakland, J. S. 1998. Total quality management. Oxford: Butterworth Heinemann. 
Rainsbury, E., D. Hodges, N. Burchell and M. Lay. 2002. Ranking workplace competencies: Student and graduate perceptions. Asia-Pacific Journal of Cooperative Education 3(2): 9-18.

Shah, M. and C. S. Nair. 2011. Employer satisfaction of university graduates: Key capabilities in early career graduates. Teaching and Learning Forum 3: 1-10.

Republic of South Africa. Department of Education. 1997. Draft White Paper on Higher Education. Pretoria. Government Printer.

RSA see Republic of South Africa.

South African National Development Plan. 2011. www.polity.org.za/article/national-developmentplan-vision-for-2030-november-2011-2011-11-14 (Accessed 14 April 2017).

Statistics South Africa. 2017. Quarterly labour force survey: Quarter 1: 2016: Statistics South Africa. http://www.statssa.gov.za/publications/PO211stQuarter2016.pdf (Accessed 27 February 2017)

Winch, C. 2006. Graduate attributes and changing conceptions. In Graduate attributes, learning and employability, ed. P. Hager and S. Holland, 67-89. Dordrecht: Springer. 